Atmos. Chem. Phys., 17, 11655-11671, 2017

https://doi.org/10.5194/acp-17-11655-2017

(C) Author(s) 2017. This work is distributed under

the Creative Commons Attribution 3.0 License.

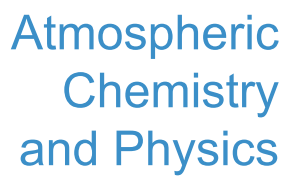

(c) (P)

\title{
Impacts of large-scale circulation on urban ambient concentrations of gaseous elemental mercury in New York, USA
}

\author{
Huiting Mao ${ }^{1}$, Dolly Hall ${ }^{2}$, Zhuyun Ye ${ }^{1}$, Ying Zhou ${ }^{1}$, Dirk Felton ${ }^{3}$, and Leiming Zhang ${ }^{4}$ \\ ${ }^{1}$ Department of Chemistry, State University of New York College of Environmental Science and Forestry, \\ Syracuse, NY 13210, USA \\ ${ }^{2}$ Department of Atmospheric and Oceanic Science, University of Maryland, College Park, MD 20742, USA \\ ${ }^{3}$ Bureau of Air Quality Surveillance, Division of Air Resources, New York State Department of Environmental Conservation, \\ Albany, NY 12233, USA \\ ${ }^{4}$ Air Quality Research Division, Science and Technology Branch, Environment and Climate Change Canada, Toronto, M3H \\ 5T4, Canada
}

Correspondence to: Huiting Mao (hmao@esf.edu)

Received: 27 February 2017 - Discussion started: 29 March 2017

Revised: 25 July 2017 - Accepted: 21 August 2017 - Published: 28 September 2017

\begin{abstract}
The impact of large-scale circulation on urban gaseous elemental mercury (GEM) was investigated through analysis of 2008-2015 measurement data from an urban site in New York City (NYC), New York, USA. Distinct annual cycles were observed in 2009-2010 with mixing ratios in warm seasons (i.e., spring-summer) 10-20 ppqv ( $\sim 10$ $25 \%$ ) higher than in cool seasons (i.e., fall-winter). This annual cycle was disrupted in 2011 by an anomalously strong influence of the US East Coast trough in that warm season and was reproduced in 2014 associated with a particularly strong Bermuda High. The US East Coast trough axis index (TAI) and intensity index (TII) were used to characterize the effect of the US East Coast trough on NYC GEM, especially in winter and summer. The intensity and position of the Bermuda High appeared to have a significant impact on GEM in warm seasons. Regional influence on NYC GEM was supported by the GEM-carbon monoxide (CO) correlation with $r$ of $0.17-0.69(p \sim 0)$ in most seasons. Simulated regional and local anthropogenic contributions to wintertime NYC anthropogenically induced GEM concentrations were averaged at $\sim 75 \%$ and $25 \%$, with interannual variation ranging over $67 \%-83 \%$ and $17 \%-33 \%$, respectively. Results from this study suggest the possibility that the increasingly strong Bermuda High over the past decades could dominate over anthropogenic mercury emission control in affecting ambient concentrations of mercury via regional buildup and possibly enhancing natural and legacy emissions.
\end{abstract}

\section{Introduction}

Atmospheric mercury $(\mathrm{Hg})$ is a prevailing pollutant that has global consequences for both human and ecosystem health, and hence $\mathrm{Hg}$ emission control is imperative. Mercury in the atmosphere is operationally defined in three forms, gaseous elemental mercury (GEM), gaseous oxidized mercury (GOM), and particulate-bound mercury (PBM). Total gaseous mercury (TGM) is the sum of GEM and GOM. The most abundant of these three forms is GEM, with a lifetime of 0.5-1 year (Driscoll et al., 2013) and mixing ratios on the order of hundreds of parts per quadrillion (ppqv) $(\sim \mathrm{a}$ few $\mathrm{ng} \mathrm{m}^{-3}$ at $1 \mathrm{ng} \mathrm{m}^{-3}=112 \mathrm{ppqv}$ in a standard atmosphere of $0^{\circ} \mathrm{C}$ and $1013.25 \mathrm{hPa}$; unit conversion was done in a standard atmosphere hereafter), compared to GOM and PBM with lifetimes of hours to weeks and mixing ratios often on the order of a single part per quadrillion $\left(\sim \mathrm{a}\right.$ few $\left.\mathrm{pg} \mathrm{m}^{-3}\right)$.

The median concentration of TGM/GEM in global continental remote areas was $1.6 \mathrm{ng} \mathrm{m}^{-3}$ (180 ppqv), estimated from a large body of measurement studies (Mao et al., 2016), and the background concentration of GEM in the Northern Hemisphere was $1.5-1.7 \mathrm{ng} \mathrm{m}^{-3}$ (168-190 ppqv) (Lindberg et al., 2007). Urban concentrations of GEM/TGM in the US varied between 0.05 and $324 \mathrm{ng} \mathrm{m}^{-3}$ (5.6-36288 ppqv) (Mao et al., 2016). In comparison, urban concentrations and their temporal variability were larger than rural, remote, and high-elevation concentrations in the Northern Hemisphere 
(e.g., Kim and Kim, 2001; Feng et al., 2003; Denis et al., 2006; Liu et al., 2007; Peterson et al., 2009; Sprovieri et al., 2010; Zhu et al., 2012; Lan et al., 2012, 2014; Chen et al., 2013; Civerolo et al., 2014; Fu et al., 2015; Brown et al., 2015; Mao et al., 2016, and references therein) owing to numerous controlling factors, including anthropogenic and legacy emissions, deposition, meteorology, transport, and atmospheric chemistry (Mao et al., 2016).

Over the US, measurements from the Atmospheric Mercury Network (AMNet) sites, located in urban, suburban, rural, and remote areas, suggested that monthly median GEM mixing ratios varied from 148 to $226 \mathrm{ppqv}$ $\left(\sim 1.32-2.02 \mathrm{ng} \mathrm{m}^{-3}\right)$, with urban values at the higher end of the range (Lan et al., 2012). Urban ambient atmospheric TGM/GEM concentrations in Canada on average ranged from 1.7 to $4.5 \mathrm{ng} \mathrm{m}^{-3}$ (190-504 $\mathrm{ng} \mathrm{m}^{-3}$ ) (Mao et al., 2016, and references therein). Urban GEM/TGM concentrations in Asia could be an order of magnitude larger than those in the US, Canada, and Europe (Mao et al., 2016, and references therein). Many studies identified local sources as a predominant factor controlling urban ambient concentrations (Gabriel et al., 2005; Lyman and Gustin, 2009; Wang et al., 2013; Feng et al., 2003; Fang et al., 2004; Zhu et al., 2012; Hall et al., 2014; Seo et al., 2016; Kim et al., 2016). In some urban locations, nighttime daily maximums and spring-summer annual peaks were attributed to local and regional sources followed by boundary layer dynamics and meteorological conditions (Liu et al., 2007, 2010; Cheng et al., 2009; Nair et al., 2012; Zhu et al., 2012). Surface emissions were also suggested to play a major role in warm season annual maximums (Denis et al., 2006; Zhu et al., 2012). Some sites experienced early morning daily maximums, with the strongest diurnal variation in summer, due possibly to local anthropogenic sources and surface emissions (Stamenkovic et al., 2007; Peterson et al., 2009). Wintertime annual maximums were probably attributed to more coal combustion to produce energy for space heating, less oxidation of GEM (Stamenkovic et al., 2007), and periods of cold and stagnant air probably leading to buildup of pollution and more $\mathrm{Hg}$ evasion prompted by wet conditions (Peterson et al., 2009). Temporal variations in GEM concentrations could be attributed to the combined influence of environmental variables, anthropogenic sources, photochemistry, and regional transport (Xu et al., 2014).

Some studies suggested that regional sources dominated over local ones in contributing to urban ambient $\mathrm{Hg}$ concentrations (e.g., Liu et al., 2007; Kim et al., 2013; Engle et al., 2010; Xu et al., 2014; Hall et al., 2014). On interannual timescales, the impact of regional transport, in comparison to local sources, could vary greatly due to large variability in atmospheric circulation and subsequently affect urban ambient concentrations very differently. Additional emission control associated with the Mercury and Air Toxics Standards (MATS) rule and the United Nations Environment Program (UNEP) international Minamata Treaty is anticipated in the future (Selin, 2014). To regulate future emissions, it is important to understand and quantify contributions of local versus regional sources to urban ambient concentrations. The objective of this paper is to examine the seasonal, annual, and interannual variability in GEM in the Bronx borough of New York City (NYC) and its relation with large-scale circulation and the contributions of local and regional sources to ambient NYC GEM concentrations.

\section{Data and approaches}

\subsection{Site description}

The site discussed herein is maintained by the New York State Department of Environmental Conservation (NYSDEC) as a part of AMNet under the National Atmospheric Deposition Program (NADP) and the National Toxics Network (NTN). The monitoring site is located on the rooftop of the Pfizer Plant Research Laboratory on the northern edge of the New York Botanical Garden in the north Bronx $\left(40^{\circ} 52^{\prime} 05^{\prime \prime} \mathrm{N}, 73^{\circ} 52^{\prime} 42^{\prime \prime} \mathrm{W}\right.$; US EPA site ID 36-005-0133). The height of the measurement point is about $9 \mathrm{~m}$ from ground surface, and winds arriving at the location are not significantly obstructed by immediate surroundings. The 100 ha New York Botanical Garden is surrounded by highways and mixed residential-commercial areas. New York City is a metropolitan area with a population $>19$ million, and the region has a long manufacturing, petrochemical, and industrial legacy that includes contamination from $\mathrm{Hg}$ and other toxic compounds. The Bronx site is also downwind of many regional sources (Fig. 1). Continuous measurements of meteorological variables and trace gas and toxic air pollutants are conducted at this site. Additional details on the site can be found on the NYSDEC website (http://www.dec.ny.gov/ docs/air_pdf/2017plan.pdf).

\subsection{Measurement data}

GEM was measured every 5 min using a Tekran (Toronto, ON) model 2537B (27 August 2008 through 24 October 2013) or 2537X (25 October 2013 onward) cold-vapor atomic fluorescence (CVAF) analyzer with a nominal detection limit of $<0.1 \mathrm{ng} \mathrm{m}^{-3}$ ( $\left.\sim 11.2 \mathrm{ppqv}\right)$. The instrument was calibrated daily with an internal permeation source. The Tekran system was operated according to standard operating procedures from the NADP's AMNet. The AMNet site liaison performs annual site visits, which include manual injections to verify the internal permeation source, and is responsible for quality assurance of the data (Civerolo et al., 2014). Additional details can be found in Landis et al. (2002) and Gay et al. (2013).

Measurement data of sulfur dioxide $\left(\mathrm{SO}_{2}\right)$, nitrogen dioxide $\left(\mathrm{NO}_{2}\right)$, carbon monoxide $(\mathrm{CO})$, temperature, wind direction, and wind speed were averaged hourly. The $\mathrm{SO}_{2}$ measurements were taken using a TEI $43 \mathrm{C}$ and a $43 \mathrm{i}$ TLE in- 


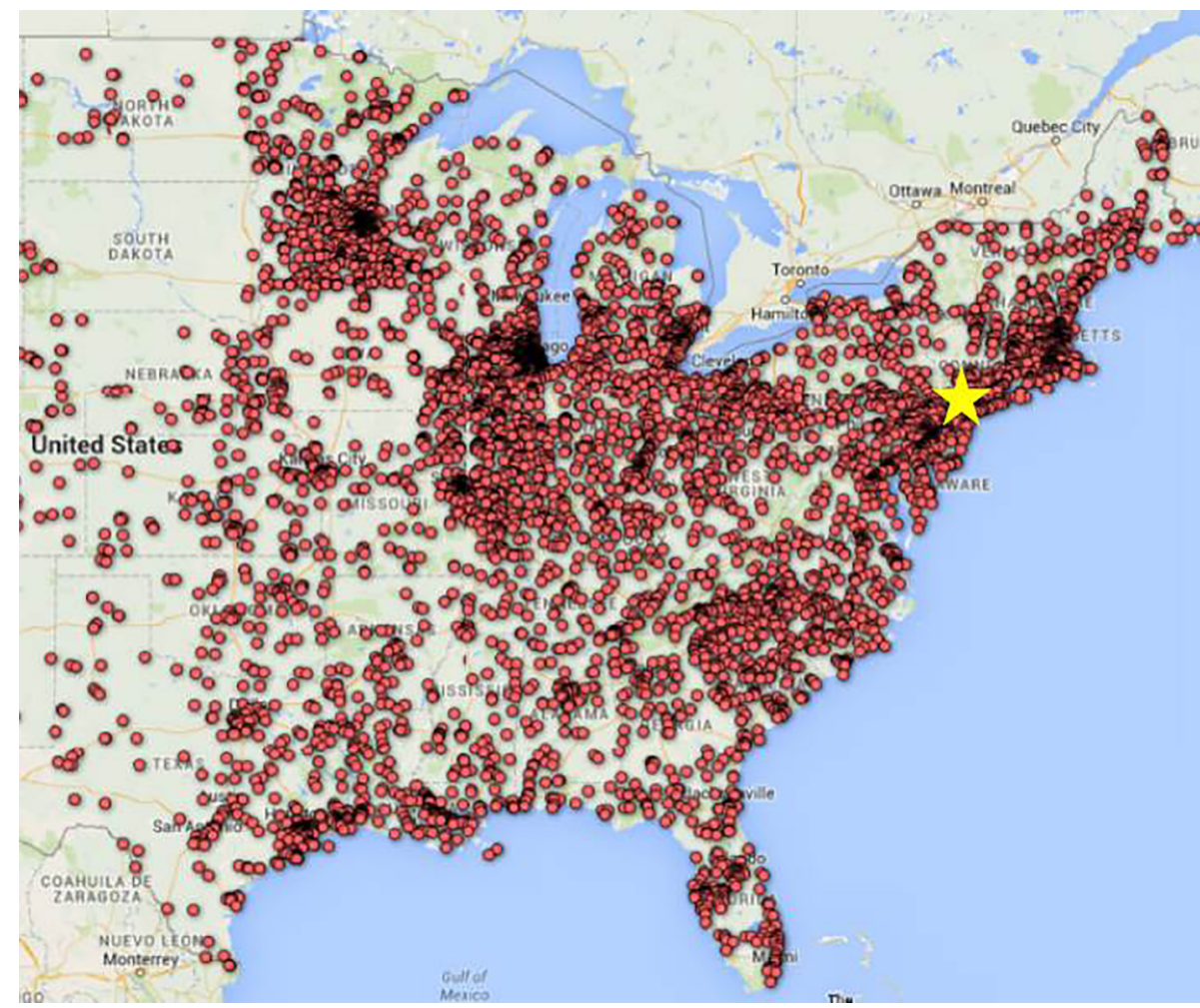

Figure 1. Map of mercury emission sources in the eastern US. The yellow asterisk marks the location of the Bronx site.

strument using pulsed fluorescence. The $\mathrm{NO}_{2}$ measurements were taken using a TEI $42 \mathrm{C}$ instrument using conversion on a heated molybdenum catalyst followed by chemiluminescence. It is acknowledged that this method is not specific to $\mathrm{NO}_{2}$ and suffers from interferences due to other oxides of nitrogen. However, in this dense urban area with ample fresh anthropogenic emissions, this artifact is relatively small in an absolute sense since nitric oxide (NO) and $\mathrm{NO}_{2}$ account for a substantial fraction of total reactive nitrogen. $\mathrm{CO}$ was measured by a TEI $48 \mathrm{C}$ and an API 300EU instrument using reference method 054 with nondispersive infrared absorption. The technical details of the deployment of these instruments are given by the NYSDEC at www.dec.ny.gov/ chemical/8541.html and in the 2016 Annual Monitoring Network Plan (www.dec.ny.gov/docs/air_pdf/2016plan.pdf).

\subsection{HYSPLIT dispersion model description, configuration, and simulation scenarios}

The impact of regional and local anthropogenic sources was simulated using the NOAA HYSPLIT Atmospheric Transport and Dispersion Modeling System (Draxler and Hess, 1997, 1998; Draxler, 1999; Stein et al., 2015) for the winters and summers of 2009-2015. HYSPLIT was driven by the EDAS $40 \mathrm{~km}$ model output over a domain extending westward to $\mathrm{OH}$, southward to northern $\mathrm{VA}$, and northward to include New England (Fig. 10a). The model was run in the forward mode for $120 \mathrm{~h}$ starting from each day of a season.

The dispersion of a pollutant is calculated by assuming a fixed number of particles being advected about the model domain by the mean wind field and spread by a turbulent component. By assigning certain mass to a particle, emissions are also incorporated in the model (Stein et al., 2015). Within the domain there was a total of 522 counties reporting $\mathrm{Hg}$ emissions that were extracted from the National Emissions Inventory (NEI) 2011 of the US Environmental Protection Agency (EPA) (https://www.epa.gov/air-emissions-inventories/ 2011-national-emissions-inventory-nei-data). Note that the total emissions of $\mathrm{Hg}$ were treated as $100 \%$ GEM emissions. The US EPA's NEI documents emissions on an annual county basis. For model simulations the EPA emission amount for each county was broken down to an hourly rate by the annual emission amount divided by $(365 \times 24)$. Two emission scenarios were designed. One scenario included emissions from all the 522 counties, and the other scenario excluded emissions from the five boroughs in NYC. Output of scenario no. 2 quantified the effect of anthropogenic emissions outside of NYC (denoted as regional sources) on NYC ambient GEM concentrations due to long-range transport only. The difference in NYC GEM concentrations between the two scenarios was used to approximate the effect of only local sources on NYC GEM concentrations. 


\subsection{Large-scale circulation analysis}

In the analysis of the US East Coast trough, the trough axis index (TAI) and trough intensity index (TII) defined by Bradbury et al. (2002) were used to quantify the position and intensity of the US East Coast trough. The seasonal TAI quantifies the mean longitudinal position of the quasi-stationary midtropospheric East Coast trough. The TAI domain extends from 120 to $30^{\circ} \mathrm{W}$ and the southern to northern boundaries ranged from 40 to $50^{\circ} \mathrm{N}$. The TAI index was calculated by averaging the longitudinal positions (Long) of the minimum $500 \mathrm{hPa}$ heights $\left(H_{\mathrm{min}}\right)$ observed at each of the four latitudinal steps $\left(j=40,42.5,45\right.$, and $\left.47.5^{\circ} \mathrm{N}\right)$ within the index range to produce a practical index in longitudinal units (relative to the prime meridian):

$\mathrm{TAI}=\operatorname{average}\left[\operatorname{Long}\left(H_{\min }\right)_{j}\right]$.

The TII is an estimate of wave amplitude at $42.5^{\circ} \mathrm{N}$ and is the mean height change at the $500 \mathrm{hPa}$ surface from equal distances east and west of the East Coast trough axis. It was calculated using

$\mathrm{TII}=\frac{\left\{\left[\left(H_{\min }\right)_{i}-H_{i+30^{\circ}}\right]+\left[\left(H_{\min }\right)_{i}-H_{i-30^{\circ}}\right]\right\}}{2}$.

The more negative TII is, the stronger the influence of the US East Coast trough would be. The $2.5^{\circ} \times 2.5^{\circ}$ reanalysis data from the National Center of Environmental Protection/National Center of Atmospheric Research were used to calculate average seasonal TAI and TII. Additional details about TAI and TII can be found in Bradbury et al. (2002).

\section{Results and discussion}

\subsection{General characteristics of diurnal, seasonal, and interannual variation}

Annual cycles of 2009, 2010, and 2014 displayed larger GEM mixing ratios ( $>$ the 75 th percentile value of the entire study) during the warm seasons (summer-spring) than the cool seasons (fall-winter) (Fig. 2, Table 1), in agreement with previous urban site studies (Denis et al., 2006; Liu et al., 2007; Zhu et al., 2012; Zhang et al., 2013; Civerolo et al., 2014). The pattern of such annual cycles was evidenced in $>20 \%(<10 \%)$ of the warm (cold) season in 2009 and 2010 and $67 \%(31 \%)$ of the warm (cold) season in 2014 experiencing larger GEM mixing ratios (Table 1). However, this pattern was not reproduced in 2011 and 2012, when the frequency of occurrence of larger GEM values was either comparable between the two seasons or slightly higher in the cold season.

Three salient features were evident in the interannual variation in a range of percentile mixing ratios of GEM (Fig. 3, Table 1). First, the 2009-2010 cool season percentile values of GEM were the lowest of all cool seasons. Second, the 2011

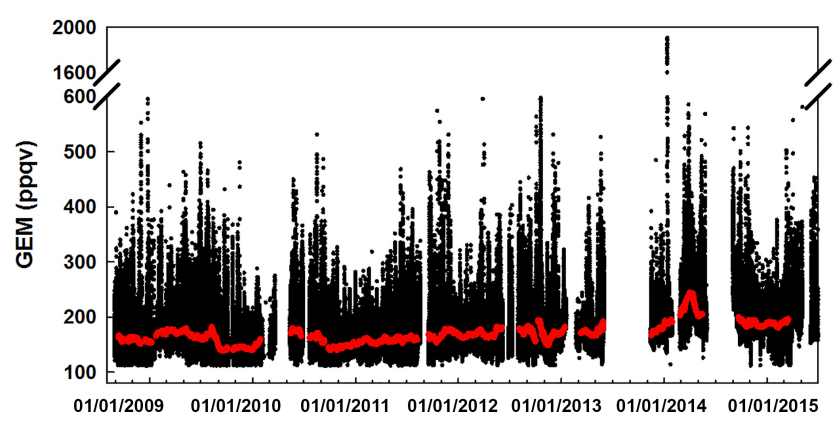

Figure 2. Time series of 5 min average GEM mixing ratios (black dots) with a 30-day running average (red line) during the study period.

warm season percentile values were the lowest of all warm seasons, even lower than in the cool season of the same year, not reproducing the 2009 and 2010 annual cycles. Third, the 2014 and 2015 seasonal percentile values were mostly the highest of the study period and for the first time since 2011, warm season values exceeded the cool season ones, reproducing the 2009 and 2010 annual cycles.

The most pronounced diurnal cycles occurred in summer, as shown in seasonal average diurnal cycles in Fig. 4, with a peak between 02:00 and 06:00 UTC and a minimum between 10:00 and 16:00 UTC, which is consistent with previous studies for urban locations (e.g., Denis et al., 2006; Liu et al., 2007; Zhu et al., 2012; Lan et al., 2012). In the summers of 2009-2012, the daily maximum was $\sim 170-190$ ppqv and the daily minimum $\sim 140-160$ ppqv. The diurnal amplitude, defined as the difference between the daily maximum and minimum, was up to $\sim 50$ ppqv in summer, $\sim 20$ ppqv in fall and spring, and $<10$ ppqv in winter.

During 2008-2013, the cool seasons experienced much larger interannual variability in GEM than the warm seasons did, whereas in 2014 and 2015 GEM concentrations were elevated significantly above other years in all seasons (Fig. 4). Over 2008-2013, the largest interannual variability of up to $\sim 40$ ppqv difference was observed between the lowest GEM mixing ratios in fall 2009 and the largest in fall 2012, whereas spring and summer experienced much less interannual variability, except spring and summer 2011, as aforementioned, which saw the lowest GEM mixing ratios, $\sim 20$ ppqv lower than all other warm seasons.

\subsection{Interannual variation of cool season GEM}

The 2009-2010 cool season exhibited the lowest percentile values, whereas most of winter 2014 and cool season 2014-2015 percentile values were the highest of the study period (Table 1, Fig. 3). The difference in percentile values between the two cool seasons ranged from 30-40 ppqv in the 25 th percentile and median values to $37-67 \mathrm{ppqv}$ in the 90 th percentile. The possible effect of anthropogenic emission changes on those interannual 
Table 1. Seasonal 10th, 25th, 75th, and 90th percentile and median mixing ratios as well as the range of GEM values from the Bronx site. Sample numbers are indicated with "Sample no.". "Frequency of higher values" represents the warm-cold seasonal frequency of GEM exceeding the 75 th percentile mixing ratio (200 ppqv) of all data.

\begin{tabular}{|c|c|c|c|c|c|c|c|c|c|}
\hline & & 10th & 25 th & Median & 75 th & 90th & Range & Sample no. & $\begin{array}{l}\text { Frequency of } \\
\text { high values }\end{array}$ \\
\hline 2008 & Fall & 132 & 142 & 160 & 187 & 217 & $112-552$ & 13677 & $14 \%$ \\
\hline \multirow[t]{4}{*}{2009} & Winter & 135 & 151 & 166 & 184 & 207 & $112-62$ & 8728 & \\
\hline & Spring & 149 & 159 & 173 & 196 & 224 & $112-463$ & 14655 & $22 \%$ \\
\hline & Summer & 134 & 147 & 166 & 195 & 234 & $112-515$ & 14986 & \\
\hline & Fall & 121 & 130 & 142 & 161 & 191 & $112-461$ & 12113 & $6 \%$ \\
\hline \multirow[t]{4}{*}{2010} & Winter & 129 & 137 & 146 & 159 & 177 & $112-288$ & & \\
\hline & Spring & 144 & 153 & 168 & 191 & 229 & $114-450$ & 4203 & $24 \%$ \\
\hline & Summer & 132 & 145 & 169 & 202 & 234 & $112-531$ & 9014 & \\
\hline & Fall & 122 & 132 & 147 & 169 & 197 & $112-1581$ & 11407 & $7 \%$ \\
\hline \multirow[t]{4}{*}{2011} & Winter & 136 & 143 & 153 & 169 & 188 & $112-318$ & 15085 & \\
\hline & Spring & 137 & 145 & 157 & 172 & 195 & $112-352$ & 15419 & $12 \%$ \\
\hline & Summer & 127 & 139 & 160 & 188 & 226 & $112-468$ & 11522 & \\
\hline & Fall & 138 & 148 & 166 & 193 & 228 & $112-660$ & 12758 & $13 \%$ \\
\hline \multirow[t]{4}{*}{2012} & Winter & 150 & 157 & 168 & 182 & 197 & 119-375 & 15117 & \\
\hline & Spring & 145 & 156 & 170 & 195 & 234 & $112-1516$ & 13708 & $23 \%$ \\
\hline & Summer & 140 & 152 & 170 & 199 & 243 & $112-445$ & 8174 & \\
\hline & Fall & 134 & 142 & 157 & 190 & 246 & 11-896 & 13210 & $25 \%$ \\
\hline \multirow[t]{4}{*}{2013} & Winter & 151 & 160 & 177 & 199 & 234 & $112-1068$ & 7781 & \\
\hline & Spring & 149 & 159 & 172 & 193 & 225 & $14-527$ & 12040 & $20 \%$ \\
\hline & Summer & - & - & - & - & - & - & - & - \\
\hline & Fall & - & - & - & - & - & - & - & - \\
\hline \multirow[t]{4}{*}{2014} & Winter & 168 & 174 & 186 & 201 & 228 & 114-1908 & 10986 & $26 \%$ \\
\hline & Spring & 179 & 194 & 216 & 248 & 296 & $126-1151$ & 15272 & $67 \%$ \\
\hline & Summer & - & - & - & - & - & - & - & - \\
\hline & Fall & 164 & 176 & 194 & 219 & 258 & $112-543$ & 12828 & $31 \%$ \\
\hline \multirow[t]{2}{*}{2015} & Winter & 159 & 176 & 186 & 198 & 214 & $112-376$ & 15218 & \\
\hline & Spring & 168 & 187 & 201 & 225 & 255 & $112-687$ & 11107 & $52 \%$ \\
\hline \multicolumn{2}{|c|}{ 2008-2015 } & 138 & 152 & 173 & 200 & 239 & $1121-1908$ & 309833 & \\
\hline
\end{tabular}

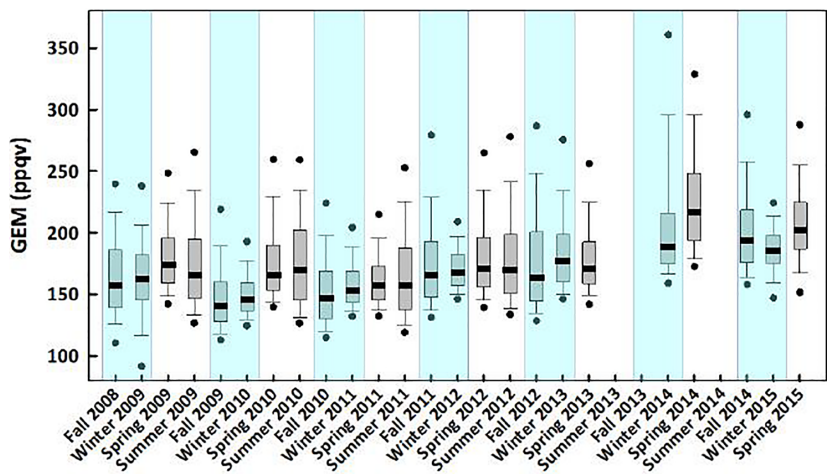

Figure 3. Seasonal 10th, 25th, 50th, 75th, and 90th GEM percentile values. The black dots represent the 5 th and 95 th percentile values. The thickened lines represent median values. The blue shaded areas are the cool season, including fall and the following winter.

variations in GEM concentrations was the very first to be examined. EPA national emission inventories showed a
$13 \%$ decrease from $2008(31810 \mathrm{~kg})$ to $2011(27695 \mathrm{~kg})$ and then an increase of $2 \%$ to $2014(28270 \mathrm{~kg})$ in total emissions from the eastern US, including states east of the Mississippi River, of which NYC emissions increased from $125 \mathrm{~kg}$ in 2008 to $145 \mathrm{~kg}$ in 2011 and to $199 \mathrm{~kg}$ in 2014 (https://www.epa.gov/air-emissions-inventories/ 2014-national-emissions-inventory-nei-data). Using an average planetary boundary layer height of $1000 \mathrm{~m}$ over the eastern US (the surface area for the eastern US is $2.483 \times 10^{12} \mathrm{~m}^{2}$ ), a decrease of $4115 \mathrm{~kg}$ from 2008 to 2011 emissions was converted to a total decrease of $200 \mathrm{ppqv}$ over all days of the three years and averaged at a decreasing rate of $0.2 \mathrm{ppqv} \mathrm{d}^{-1}$, and an increase of $575 \mathrm{~kg}$ from 2011 to 2014 emissions was converted to a rate of $\sim 0.03 \mathrm{ppqv} \mathrm{d}^{-1}$. The potential change in NYC atmospheric concentrations was estimated to be $\sim 3 \mathrm{ppqv} \mathrm{d}^{-1}$ from the 2008-2011 NYC emission increases alone and $\sim 6$ ppqv d $^{-1}$ from the 2011-2014 increase. The potential changes in ambient concentrations caused by the regional emission decrease-increase were negligible compared to the observed 

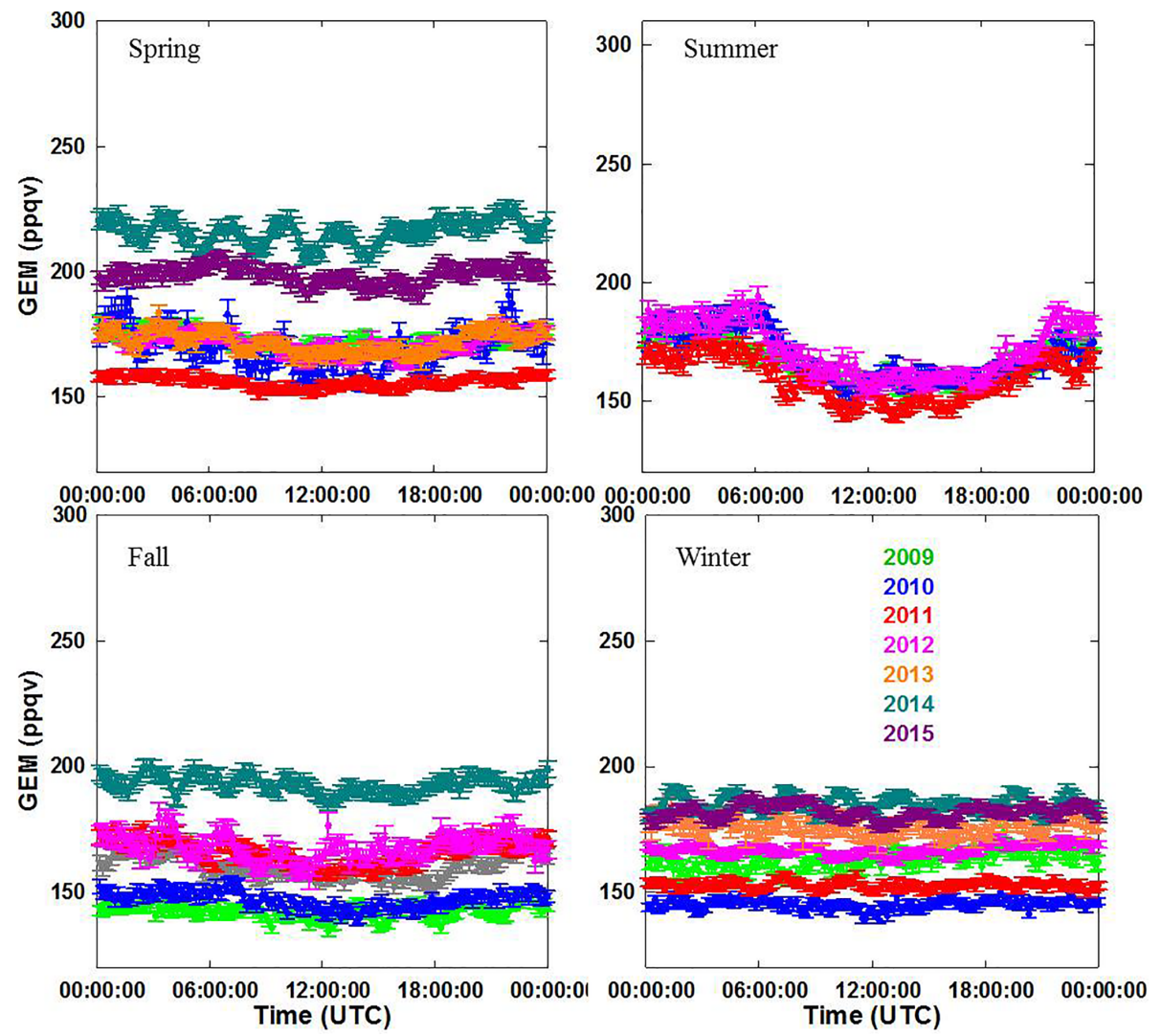

Figure 4. Averaged seasonal diurnal cycles of GEM for spring, summer, fall, and winter.

interannual difference. Those possibly caused by NYC emission increases could be significant but appeared to be inconsistent with the changes in ambient concentrations in two ways. First, from 2010 to 2011 NYC emissions increased and yet summertime ambient concentrations decreased by 10 ppqv throughout the averaged seasonal diurnal cycle (Fig. 4). Second, if the residence time of emitted GEM was 1 day, the total increase in ambient mixing ratio would be $6 \mathrm{ppqv} \mathrm{d}^{-1}$ due to anthropogenic emission increases and would be even smaller, spreading throughout the day, which was negligible compared to the $\sim 60$ ppqv increase observed in the spring 2011 average seasonal diurnal cycle compared to the spring 2014 one (Fig. 4). The contribution from the NYC anthropogenic emissions to ambient GEM was further demonstrated using the HYSPLIT simulations in Sect. 5.

Legacy and natural emissions could be another driver for the observed interannual variations in GEM. However, seasonal mean temperature and GEM from the Bronx location were not found to be correlated, which suggested that the effect of changes in legacy and natural emissions on ambient GEM might not be dominant. In addition, using the estimated annual natural and re-emissions of 9.4 to $13.0 \mu \mathrm{g} \mathrm{m}^{-2}$ from Zhang et al. (2016) for the Bronx site during 20092014 , the maximum year-to-year change was calculated to be $\sim 1$ ppqv d $^{-1}$, assuming an average planetary boundary layer height of $1000 \mathrm{~m}$. This change alone could not explain the observed interannual variations. It alludes to the potential effect of regional legacy and natural emissions as well as chemistry, which needs to employ modeling tools and is beyond the scope of this study. Here, it was hypothesized that atmospheric circulation was one predominant factor contributing to the observed interannual variation in ambient Bronx GEM concentrations.

To validate this hypothesis, circulation patterns were examined first using the Bronx site wind data. In the falls of 2008, 2009, 2011, and 2013, wind came from all four quadrants, with comparable frequency ranging from 15 to $30 \%$ of the season, whereas in fall 2010 the northwesterly (270$\left.360^{\circ}\right)$ was more frequent $(37 \%)$, and the northeasterly $(0$ $\left.90^{\circ}\right)$ became predominant $(\sim 50-74 \%)$ in the falls of 2012 and 2014 (Fig. 5a). The winters experienced northwesterly winds $\left(270-360^{\circ}\right)$ more often ranging from $\sim 40$ to $65 \%$ of the season, with the exception of winter 2015 when a little below $40 \%$ of the season experienced northwesterly winds, on par with southwesterly wind $\left(180-270^{\circ}\right)$ (Fig. 5a). Wind speed was averaged seasonally for the four wind quadrants (Fig. 5b). Northwesterly wind $\left(270-360^{\circ}\right)$ was the strongest $\left(>3 \mathrm{~m} \mathrm{~s}^{-1}\right.$ ) in the winters and springs of 2009-2013 and was reduced to $\sim 2 \mathrm{~m} \mathrm{~s}^{-1}$ in 2014 and 2015. Southwesterly (180$270^{\circ}$ ) wind hovered around $2 \mathrm{~m} \mathrm{~s}^{-1}$ in the cool seasons, ex- 

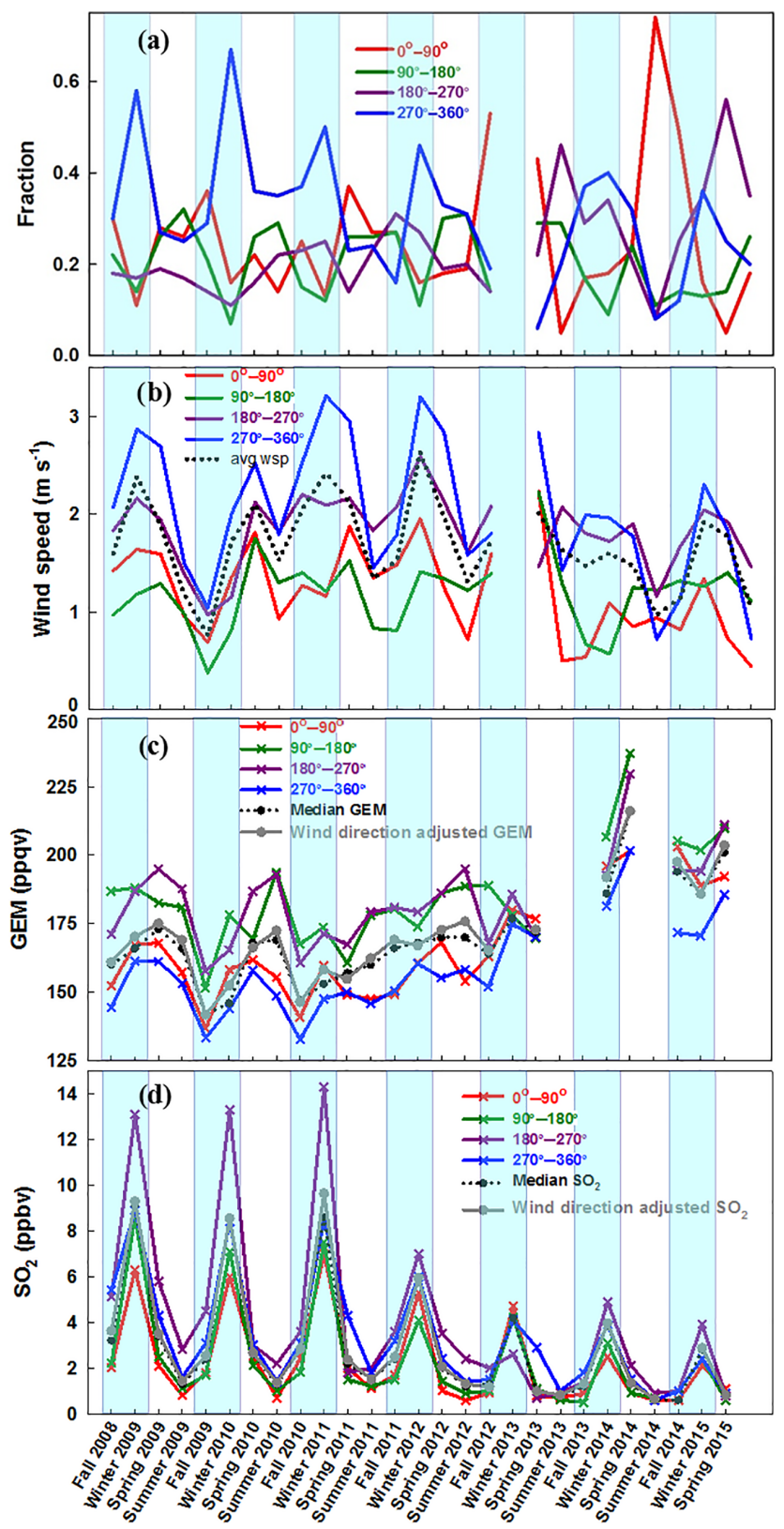

Figure 5. (a) Fraction of wind coming from (b) wind speed, (c) GEM, and (d) $\mathrm{SO}_{2}$ averaged in the four wind quadrants in each season together with seasonal median and wind-direction-adjusted values. The shaded areas indicate the cool seasons. In (b) the dotted black line indicates the wind speed averaged in all directions. In (c) and (d) the dotted black line and solid black dots represent the overall seasonal median values of GEM and $\mathrm{SO}_{2}$, and the dotted dark grey line and solid dark grey dots represent the wind direction adjusted GEM and $\mathrm{SO}_{2}$ values.

cept 2009-2010 when it decreased to $1 \mathrm{~m} \mathrm{~s}^{-1}$. Wind speed in the two easterly quadrants $\left(0-180^{\circ}\right)$ varied comparably from 1 to $2 \mathrm{~m} \mathrm{~s}^{-1}$, except in spring 2013 when it reached $2.5 \mathrm{~m} \mathrm{~s}^{-1}$ and was particularly low $\left(0.5 \mathrm{~m} \mathrm{~s}^{-1}\right)$ in the 2014 cool season.
Since anthropogenic $\mathrm{Hg}$ sources are mostly concentrated to the west, southwest, south, and northeast of the Bronx site with much fewer sources to the northwest (Fig. 1), GEM mixing ratios would vary expectedly corresponding to air masses arriving from different directions. This was clearly suggested by mixing ratios of GEM averaged seasonally for the four wind quadrants (Fig. 5c). Generally, seasonally averaged GEM mixing ratios were larger by $\sim 20-50$ ppqv in the two southerly quadrants than those in the northerly quadrants. Overall, in addition to local emissions, interannual variability in the origin of the air masses reaching the Bronx appeared to cast significant influence on the ambient concentrations of GEM in the city. This argument was strongly supported by $\mathrm{SO}_{2}$ values in the four wind quadrants (Fig. 5d). Consistent with GEM (Fig. 5c), southwesterly (180-270 ) wind brought in air masses with the highest $\mathrm{SO}_{2}$ levels in 2008-2011, especially in winter, reaching 13-14 ppbv, followed by half the values in the winters of 2012-2015. In contrast, the $\mathrm{SO}_{2}$ mixing ratios were close in the other three wind quadrants. One difference between the variation patterns of GEM and $\mathrm{SO}_{2}$ in the four wind quadrants was that air masses from the southeast appeared to also be rich in GEM, whereas $\mathrm{SO}_{2}$ in air from the southeast was low, close to that from the northwest and northeast. One confounding factor for this difference could be due to the ocean being a major source of GEM, and also the only landmass southeast of the Bronx is Long Island, with limited major polluters.

Two cases, the lowest percentile values in the 2009-2010 cool season and the highest in 2014-2015 were used to elaborate on this point. What was most striking about the 2009$2010 \mathrm{cool}$ season was the very low frequency $(14 \%)$ of wind from the southwesterly quadrant $\left(180-270^{\circ}\right)$ in fall 2009 and the largest frequency of wind from the northwesterly quadrant $\left(67 \%, 270-360^{\circ}\right)$ in winter 2010 combined with nearly the lowest wind speed $\left(\leq 1 \mathrm{~m} \mathrm{~s}^{-1}\right)$ in the three quadrants $\left(0-270^{\circ}\right)$ (Fig. 5a-c). This indicates that the particularly low mixing ratios in the cool season of 2009-2010 were likely caused by an influx of relatively cleaner Canadian air masses that were over 4 times more frequent and the slowest southerly flow of more polluted air.

The second case is winter 2014 when GEM averaged in the four wind quadrants reached the maximums of all time (Fig. 5c). Coincidently the frequency of wind from the northwesterly quadrant $\left(270-360^{\circ}\right)$ was nearly the lowest of all cool seasons, barely reaching $40 \%$ of the season compared to up to $67 \%$ in winter 2010 (Fig. 5a). Meanwhile, the frequency of wind from the southwesterly quadrant (180 $270^{\circ}$ ) reached a high of $34 \%$ of all cool seasons, and the wind speed of $\sim 2 \mathrm{~m} \mathrm{~s}^{-1}$ was comparable to the northwesterly quadrant. This is a strong indication of the arrival of air masses rich in GEM originating from the heavy emitters in the northeastern US urban corridor via flow nearly as frequent and as fast as the relatively clean northwesterly quadrant. Winter 2015 showed similar wind patterns, also coinciding with high GEM concentrations. 


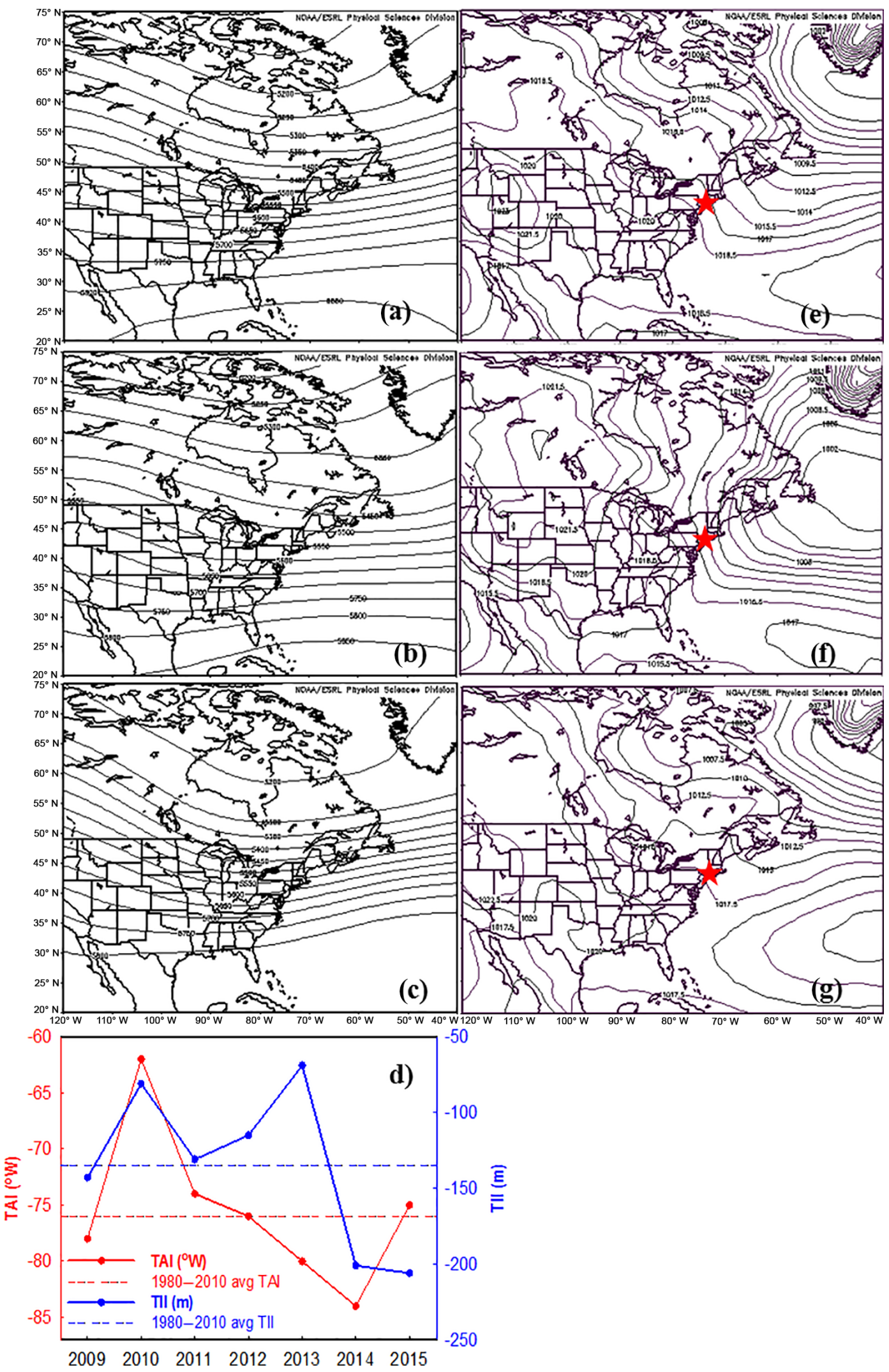

Figure 6. September-February $500 \mathrm{hPa}$ GPH for (a) 1980-2010, (b) 2010, and (c) 2014; North American TAI and TII for the winters of 2009-2015 (d); sea level pressure averaged over the winters of 1980-2010 (e), winter 2010 (f), and winter 2014 (g). The red asterisks indicate the location of the Bronx site. Courtesy: NOAA ESRL PSD Interactive Climate Analysis. 
Such variations in wind direction and speed at the Bronx site can be better understood in the context of large-scale circulation. The climatological $500 \mathrm{hPa}$ geopotential height (GPH) (1980-2010) for cool seasons during 1980-2010 exhibited the US East Coast trough centered over coastal southeastern Canada extending southwestward over the eastern US (Fig. 6a). All cool seasons experienced variations in this pattern, except the cool seasons of 2009-2010 and 2013-2014, which appeared to be anomalous (Fig. 6b and c). Specifically, the trough in winter 2010 shifted eastward farthest out over the ocean and was the weakest, evidenced in the maximum TAI $\left(62^{\circ} \mathrm{W}\right)$ and nearly the least negative TII value $(-80 \mathrm{~m})$ (Fig. 6d). In contrast, the trough in winter 2014 was situated the farthest over land and had the strongest of all winters, backed by the most negative TAI $\left(85^{\circ} \mathrm{W}\right)$ and nearly the most negative TII value (-201 m) (Fig. 6d). This suggested that in winter 2010 the northeast US was most frequently under the influence of air masses from higher latitudes via flow on the backside of the US East Coast trough, whereas this was much less prevalent in winter 2014 due to the eastern US in winter 2014 being positioned near the axis in the front of the trough. This was further clearly reflected in the maps of sea level pressure (SLP) for the two winters. The unusual winter 2010 circulation was signified by northerly gradient flow (Fig. 6f) from the backside of the Icelandic Low, which shifted toward the south and west near Newfoundland compared to its 1980-2010 climatological position right between and below Greenland and Iceland (Fig. 6e). This indicated predominant transport of relatively clean air from Canada combined with strong ventilation of continental pollution, likely leading to the least polluted air in winter 2010 of all seven winters. In contrast, in winter 2014 NYC appeared to be on the periphery of high-pressure systems in predominantly slow northwesterly and southwesterly flow regimes (Fig. 6g). This explains the least frequent, lowest wind speed in the easterly wind quadrants during winter 2014 (Fig. 5b), which is conducive to regional buildup of air pollution, resulting in the highest mixing ratios of GEM of all winters. More evidence was shown in Sect. 6 using modeled contributions to NYC ambient concentrations from local versus regional anthropogenic sources.

\subsection{Interannual variation in warm season GEM}

\subsubsection{Annual maximums in warm seasons of 2009 and 2010}

The annual cycles of GEM at the Bronx site in 2009 and 2010, with larger values in spring and summer (Table 1; Figs. 2 and 3), are consistent with measurements from some urban and industrial locations in the literature (Lindberg and Stratton, 1998; Liu et al., 2007; Zhu et al., 2012; Xu et al., 2014). Lindberg and Stratton (1998) and Liu et al. (2007) attributed such annual cycles to local anthropogenic sources, while Zhu et al. (2012) and $\mathrm{Xu}$ et al. (2014) speculated re- emission from soils to be a potential dominant factor. In NYC, impervious surfaces comprise $95 \%$ of the total land surface (Adler and Tanner, 2013), which, considering local sources alone, makes re-emission of $\mathrm{Hg}$ from soils much less significant than anthropogenic emissions from the area. Indeed, no correlation between seasonal temperature and GEM was found for the Bronx site (not shown). It thus seemed unlikely that NYC legacy emissions contributed to the 2009 and 2010 annual cycles. The impact of regional vs. local anthropogenic sources on NYC GEM concentrations was studied in Sect. 3.5, and quantifying the impact of regional natural and legacy emissions calls for a regional modeling approach, which is beyond the scope of this study. Here we focused on the potential impact of large-scale circulation on NYC GEM concentrations.

In the warm seasons, the Bronx was on the periphery of the Bermuda High (Fig. 7c, f), where usually lower wind speed prevailed. This is consistent with the annual cycle of wind speed shown in Fig. 5b, with wind mostly lower in spring-summer and higher in fall-winter conducive to regional pollution buildup, which could explain why the Bronx saw larger peaks in GEM in the warm season than in the cool season.

\subsubsection{Lowest GEM in warm season 2011 and highest in 2014-2015}

In examining wind in the warm season of 2011, what stood out was that the Bronx experienced a significantly increased frequency $(37 \%)$ of northeasterly wind of $\sim 2 \mathrm{~ms}^{-1}$ in spring and a decreased frequency of $(20 \%)$ of northwesterly wind in summer compared to the spring and summer in 2009 and 2010 (Fig. 5a). In summer 2014 nearly $80 \%$ of the season had northeasterly wind $\left(0-90^{\circ}\right)$ and there was unusually weak wind $\left(\sim 1 \mathrm{~m} \mathrm{~s}^{-1}\right)$ in all four wind quadrants (Fig. 5a, b), which suggested calm conditions. In the warm season of 2011, GEM concentrations in the northeasterly wind quadrant were averaged at $\sim 145 \mathrm{ppqv}$, up to $\sim 20$ ppqv lower than those in the most polluted southerly quadrants (Fig. 5c). In contrast, the springs of 2014 and 2015 GEM in the northeasterly quadrant were averaged at 200 and 192 ppqv, respectively, equally large or even larger than GEM in the other three quadrants (Fig. 5c). The unusually high concentration was an indication of buildup under calm conditions.

The anomalously increased occurrence of northeasterly wind in summer 2011 indicated unusual circulation. Compared to the 1980-2010 climatology, the $500 \mathrm{hPa}$ GPH in spring 2011 showed the weakest US East Coast trough of all springs (Fig. S1), evidenced in the westernmost trough axis position $\left(\mathrm{TAI}=108^{\circ} \mathrm{W}\right)$ and the smallest intensity $(\mathrm{TII}=-27 \mathrm{~m}$ ) of all springs (Fig. 7a). The $500 \mathrm{hPa}$ GPH in summer 2011 suggested the strongest US East Coast trough $(\mathrm{TII}=-87 \mathrm{~m})$ and the second easternmost trough axis position $\left(\mathrm{TAI}=66^{\circ} \mathrm{W}\right)$ of all summers (Figs. 7b, S2). This 

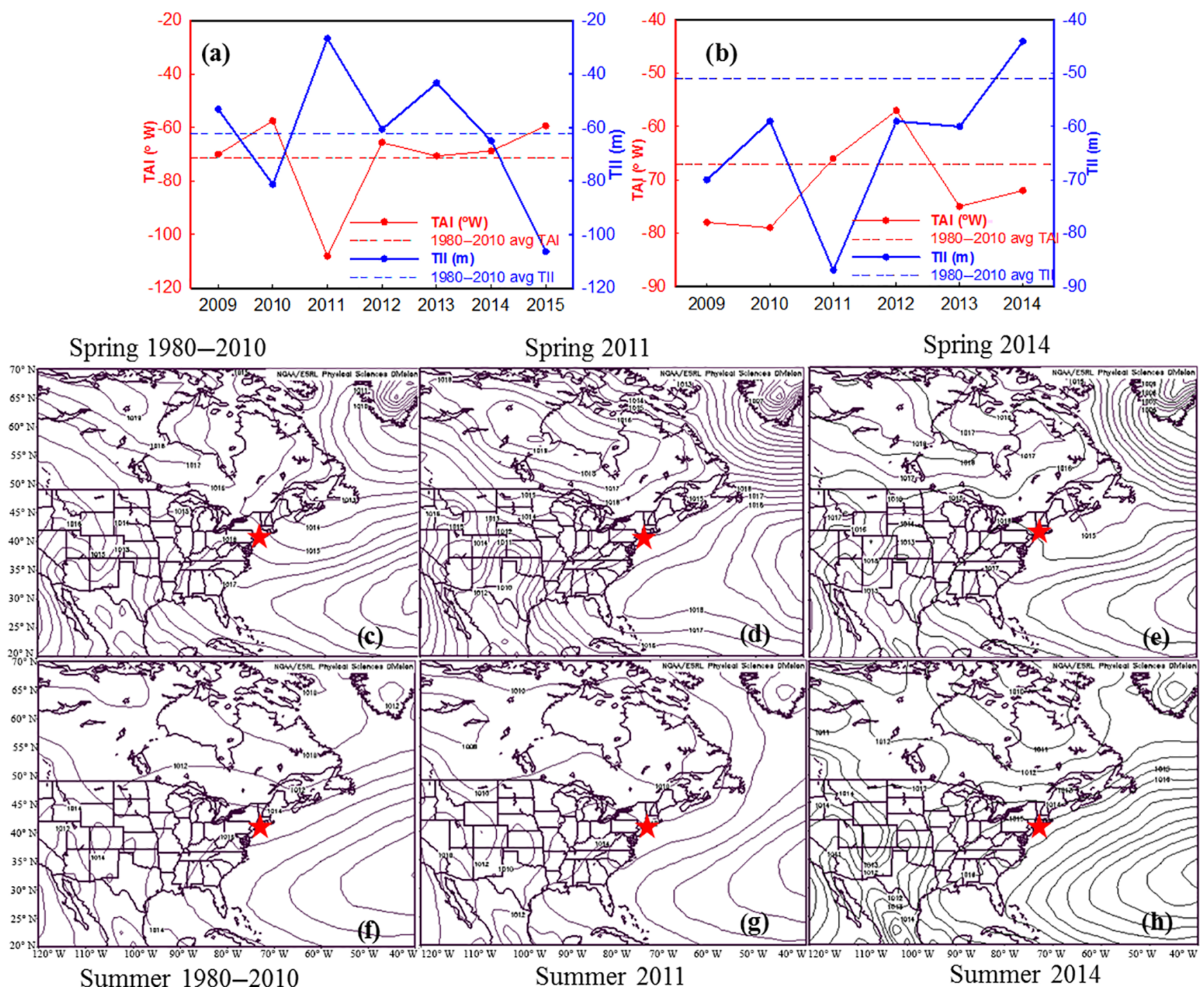

Figure 7. The axis position (TAI) and intensity (TII) of the $500 \mathrm{hPa}$ North American trough in spring (a) and summer (b). Sea level pressure (SLP) in the springs of (c) 1980-2010, (d) 2011, and (e) 2014. SLP in the summers of (f) 1980-2010, (g) 2011, and (h) 2014. The red asterisks indicate the Bronx site location. Courtesy: NOAA ESRL PSD Interactive Climate Analysis.

suggests that the northeastern US in summer 2011 was frequently under significant influence of the backside of the trough, i.e., sweeping air flow from higher latitudes subsiding to the surface in midlatitudes.

Near the surface, the 1980-2010 SLP climatology suggested that in spring NYC was situated in the gradient flow of the Bermuda High and a trough from the Icelandic Low (Fig. 7c), conducive to transport of emissions from upstream source regions such as upstate New York, Ohio, and Pennsylvania, while in summer NYC is under the influence of the Bermuda High, which is favorable for regional buildup (Fig. 7f). However, in spring 2011, the trough of the Icelandic Low gave way to the Canadian High, leaving NYC locked in a zone between the Canadian High and subtropical high (Fig. 7d), possibly cutting regional transport short in addition to strong subsidence of cleaner higher-latitudinal air, leading to the lowest concentrations of GEM of all springs. Similarly unusual was summer 2011 when NYC was under less influence from the Bermuda High than from the US East Coast trough, which is unfavorable for regional buildup (Fig. $7 \mathrm{~g}$ ). These speculations appeared to be consistent with the fact that both seasons saw unusual equal chances of winds from the four quadrants (Fig. 5a) over the Bronx and its surrounding areas.

The $500 \mathrm{hPa}$ TAI and TII values (Fig. 7b) and the $500 \mathrm{hPa}$ GPH map (Fig. S2) in summer 2011 suggested the strongest $(\mathrm{TII}=-87 \mathrm{~m})$ and second easternmost $\left(\mathrm{TAI}=66^{\circ} \mathrm{W}\right) \mathrm{US}$ East Coast trough. In comparison, summer 2014 (Fig. S2) saw the weakest US East Coast trough $(\mathrm{TII}=-44 \mathrm{~m})$ of all summers, with its axis on average at $72^{\circ} \mathrm{W}$, near the East 
Coast. This contrast indicates that summer 2011 experienced the weakest influence of the Bermuda High on the East Coast (Fig. 7e, h) of all summers during the study period, the polar extreme of the 2014 warm season. Correspondingly, the spring and summer 2014 SLP maps (Figs. S3 and S4) exhibited the Bermuda High ridge over the eastern US more northextending than in other years, which is consistent with weak winds in all directions as shown in Fig. 5b. This dynamic situation led to regional buildup conducive to the highest GEM mixing ratios in all wind quadrants.

To be quantitative, domain-average SLP, the number of grids with SLP exceeding $1014 \mathrm{hPa}$ over the domain (25$50^{\circ} \mathrm{N}, 95-70^{\circ} \mathrm{W}$ ), the northernmost latitude, and westernmost longitude of the $1014 \mathrm{hPa}$ isobar, were examined to gauge the intensity and spatial extent of the influence of the Bermuda High. The domain-average SLP and the number of grids with SLP $>1014 \mathrm{hPa}$ turned out to be best correlated ( $r=0.95, p=0.05 ; r=0.99, p=0.006)$ with summer season median GEM (Fig. 8). The lowest GEM in summer 2011 was associated with the weakest influence of the Bermuda High indicated by the lowest domainaverage SLP (1013 hPa) and least number (63) of grids with SLP $>1014 \mathrm{hPa}$ of all summers. Meanwhile, the US East Coast trough reached as far down south as North Carolina (Fig. S4), consistent with the most negative TII (-90 m), as aforementioned and shown in Fig. 7b. This indicates more widespread influence of relatively clean Canadian air on the eastern US, sweeping out the heavily polluted air in the region. One may argue that the positive correlation shown above appears to be driven by the four points in summers 2009-2012 due to missing and/or unavailable data in summers 2013 and 2014. It should be noted that the increases in GEM started in winter 2014, consistently evidenced in measurements available through spring 2015 compared to all previous years (Fig. 3). Therefore, the large increase in the 2014 warm season was most likely not fortuitous, and more importantly such increases were consistent with the driving dynamical mechanisms as suggested in the large-scale circulation.

It should be noted that the seasonal median GEM values in the four wind quadrants exhibited trends largely consistent with those in the overall seasonal values $(r=0.87-0.95$, $p \sim 0$ ) (Fig. 5c). This suggests that changes in ambient mixing ratios occurred in air masses coming from all directions, whether they were from the relatively clean northwest and northeast or the heavily polluted regions southeast and southwest of the Bronx. A possible explanation is that the lifetime of GEM is long enough for air from all wind directions to be regionally mixed. The fact that the GEM values in the two relatively more polluted quadrants exhibited excellent correlations with the overall values suggested that the trend in the ambient GEM mixing ratio was largely shaped by the variability in anthropogenic influence. Such influence may not necessarily be driven by changes in anthropogenic emissions

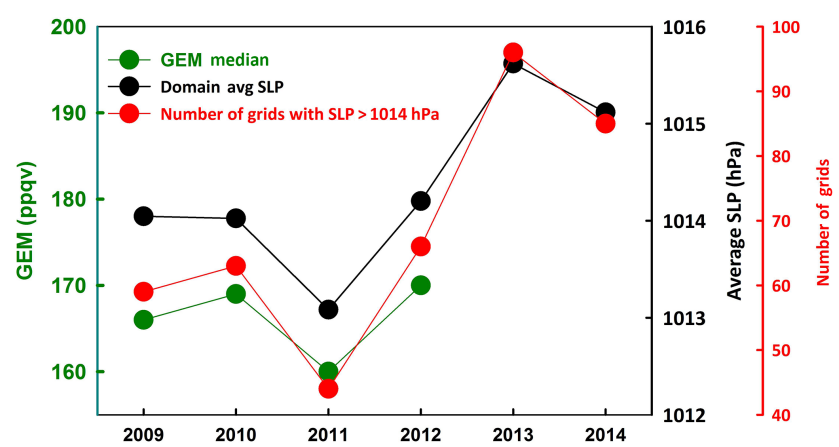

Figure 8. Average sea level pressure (SLP) over the domain of 25$50^{\circ} \mathrm{N}, 95-70^{\circ} \mathrm{W}$ (black), number of grids with SLP $>1014 \mathrm{hPa}$ (red), and seasonal median GEM mixing ratios (dark green) in the summer.

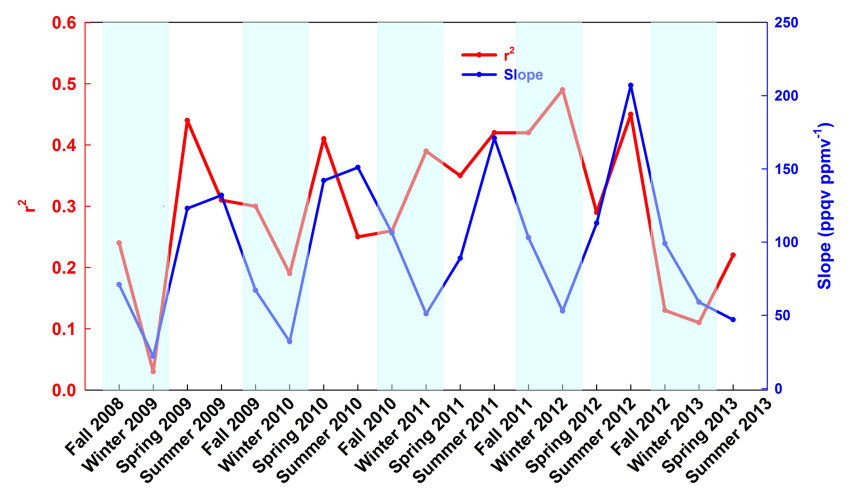

Figure 9. Values of $r^{2}$ (red) and slope (blue) of GEM-CO correlation during each season from 2008 to 2013. All $r^{2}$ values were statistically significant with $p$ approaching 0 .

but could be caused by strong ventilation or regional buildup of pollution as demonstrated in earlier discussions.

\subsection{Relationships between GEM and anthropogenic tracers}

Correlations between $\mathrm{Hg}$ and several tracers (e.g., $\mathrm{CO}, \mathrm{SO}_{2}$, and $\mathrm{NO}_{2}$ ) have been commonly used to identify $\mathrm{Hg}$ anthropogenic sources, source-receptor relationships, and/or emission ratios. The linear correlation between CO and GEM, especially in winter, in rural locations despite their different sources, reflects their emission ratios in regionally wellmixed air masses (e.g., Mao et al., 2008). At the Bronx site, seasonal GEM and $\mathrm{CO}$ values were found to be correlated with $r$ up to $0.69(p \sim 0)$ in all seasons during 2008-2013, indicating significant, year-round regional influence, and the two were notably not or minimally correlated in all the seasons from winter 2014 through spring 2015. During 20082010 and $2012 r^{2}$ values of GEM-CO were larger in warm than in cold seasons, with the maximums exceeding 0.40 , and $r^{2}$ values remained high from winter 2011 through winter 2012 (Fig. 9). The slope value varied from the smallest 
Table 2. Pearson correlation coefficients $(r)$ between GEM and $\mathrm{SO}_{2}$ and between GEM and $\mathrm{NO}_{2}$ with $p$ values in parentheses, for seasons during fall 2008-spring 2015.

\begin{tabular}{|c|c|c|c|c|}
\hline & \multicolumn{2}{|c|}{ All data } & \multicolumn{2}{|c|}{$\mathrm{SO}_{2}$ and $\mathrm{NO}_{2}$ for $\mathrm{GEM}>95$ th percentile } \\
\hline & $\mathrm{SO}_{2}$ & $\mathrm{NO}_{2}$ & $\mathrm{SO}_{2}$ & $\mathrm{NO}_{2}$ \\
\hline Fall 2008 & $-0.02(=0.371)$ & $0.32(<0.0001)$ & $0.07(=0.502)$ & $-0.08(=0.476)$ \\
\hline Winter 2009 & $0.26(<0.0001)$ & $0.41(<0.0001)$ & $-0.20(=0.132)$ & $-0.02(=0.875)$ \\
\hline Spring 2009 & $0.01(=0.608)$ & $0.05(=0.03)$ & $-0.02(=0.832)$ & $0.09(=0.41)$ \\
\hline Summer 2009 & $0.16(<0.0001)$ & $0.46(<0.0001)$ & $0.50(<0.0001)$ & $0.25(=0.0152)$ \\
\hline Fall 2009 & $0.25(<0.0001)$ & $0.53(<0.0001)$ & $0.08(=0.505)$ & $0.15(=0.190)$ \\
\hline Winter 2010 & $0.42(<0.0001)$ & $0.55(<0.0001)$ & $0.03(=0.794)$ & $0.05(=0.693)$ \\
\hline Spring 2010 & $0.07(=0.094)$ & $0.38(<0.0001)$ & $-0.13(=0.507)$ & $0.13(=0.505)$ \\
\hline Summer 2010 & $0.10(<0.0001)$ & $0.45(<0.0001)$ & $-0.07(=0.605)$ & $0.22(=0.105)$ \\
\hline Fall 2010 & $0.06(=0.0101)$ & $0.36(<0.0001)$ & $0.09(=0.403)$ & $0.00(=0.972)$ \\
\hline Winter 2011 & $0.51(<0.0001)$ & $0.71(<0.0001)$ & $-0.20(=0.0464)$ & $-0.03(=0.802)$ \\
\hline Spring 2011 & $0.01(=0.761)$ & $0.41(<0.0001)$ & $0.01(=0.901)$ & $0.24(=0.0156)$ \\
\hline Summer 2011 & $0.14(<0.0001)$ & $0.53(<0.0001)$ & $-0.12(=0.285)$ & $0.11(=0.296)$ \\
\hline Fall 2011 & $0.22(<0.0001)$ & $0.51(<0.0001)$ & $0.34(=0.0018)$ & $0.26(=0.0185)$ \\
\hline Winter 2012 & $0.20(<0.0001)$ & $0.57(<0.0001)$ & $0.00(=0.986)$ & $0.27(=0.0078)$ \\
\hline Spring 2012 & $0.13(<0.0001)$ & $0.44(<0.0001)$ & $-0.12(=0.268)$ & $-0.16(=0.125)$ \\
\hline Summer 2012 & $0.29(<0.0001)$ & $0.49(<0.0001)$ & $-0.10(=0.475)$ & $0.02(=0.903)$ \\
\hline Fall 2012 & $-0.15(<0.0001)$ & $0.13(<0.0001)$ & $-0.43(<0.0001)$ & $-0.46(<0.0001)$ \\
\hline Winter 2013 & $0.10(=0.0016)$ & $0.37(<0.0001)$ & $-0.23(=0.101)$ & $-0.31(=0.0196)$ \\
\hline Spring 2013 & N/A & N/A & N/A & N/A \\
\hline Summer 2013 & N/A & N/A & N/A & N/A \\
\hline Fall 2013 & N/A & N/A & N/A & N/A \\
\hline Winter 2014 & $-0.12(<0.0001)$ & $0.04(=0.13)$ & $-0.47(<0.0001)$ & $0.21(=0.0944)$ \\
\hline Spring 2014 & $0.07(=0.003)$ & $0.39(<0.0001)$ & $0.05(=0.608)$ & $0.05(=0.654)$ \\
\hline Summer 2014 & N/A & N/A & N/A & N/A \\
\hline Fall 2014 & $-0.13(<0.0001)$ & $0.33(<0.0001)$ & $0.11(=0.362)$ & $0.02(=0.887)$ \\
\hline Winter 2015 & $0.27(<0.0001)$ & $0.60(<0.0001)$ & $-0.07(=0.570)$ & $-0.07(=0.555)$ \\
\hline Spring 2015 & $0.13(<0.0001)$ & $0.52(<0.0001)$ & $0.05(=0.656)$ & $0.07(=0.557)$ \\
\hline
\end{tabular}

$\left(\sim 0.02-0.03 \mathrm{ppqv}_{\mathrm{ppbv}}{ }^{-1}\right)$ in winters of 2009-2010 to the largest $\left(0.21 \mathrm{ppqv} \mathrm{ppbv}^{-1}\right)$ in summer 2012 (Fig. 9), with the largest higher than the upper end of the range, 0.060.14 ppqv ppbv $^{-1}$, from rural southern New Hampshire during winters 2004-2007 (Mao et al., 2008). This was greatly different from the GEM-CO correlation in rural southern New Hampshire in winter only due to confounding factors such as legacy emissions and wet deposition in summer (Mao et al., 2008; Lombard et al., 2011). The Bronx experiencing more significant GEM-CO correlation in warm seasons indicated better regionally mixed air masses, influenced predominantly by anthropogenic emissions, than in cool seasons. This is consistent with the cool and warm seasonal circulation patterns as discussed in Sect. 3.2 and 3.3, which is that in warm seasons NYC was predominantly under the influence of the subtropical high conducive to regional mixing and buildup of pollutants.
No correlation between GEM and CO during 2014-2015 could be due in part to the more dramatic emission reductions in $\mathrm{CO}$ than changes in GEM in the eastern US. The high percentile values of $\mathrm{CO}$ at the Bronx site had been affected by anthropogenic emission reductions over the years, while the 10th and 25th percentile values (referred to as baseline $\mathrm{CO}$ in the literature) remained fairly constant in all seasons (Fig. S5). Zhou et al. (2017) suggested that baseline CO in rural northeastern US areas was controlled by a multitude of factors, including global biomass emissions, large-scale circulation, and cyclone activity. At the Bronx site, the low percentile value, close to regional baseline levels, was possibly determined by a range of factors, whose importance could have varied from year to year.

Unlike previous studies (e.g., Jen et al., 2013; Choi et al., 2013), GEM at the Bronx site was found to be poorly correlated with $\mathrm{SO}_{2}$ while somewhat to moderately correlated with $\mathrm{NO}_{2}(r=0.13-0.71, p<0.0001)$ (Table 2), despite 

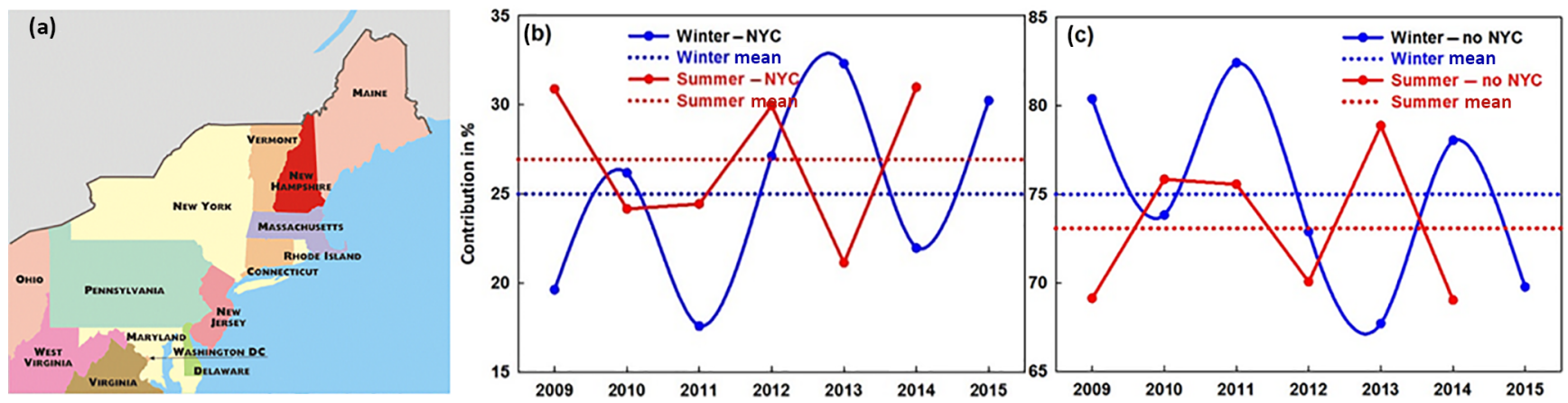

Figure 10. (a) Counties and states that contributed to Hg in NYC; (b) contributions (\%) of NYC sources to NYC Hg concentrations; (c) contributions (\%) of sources outside of NYC to NYC Hg concentrations in winter (blue) and summer (red).

abundant sources co-emitting GEM, $\mathrm{SO}_{2}$, and $\mathrm{NO}_{2}$ locally and upwind. In addition to different lifetimes, different magnitude and timing of emission reduction implementations and source types of the three compounds could have affected their relation. Total $\mathrm{Hg}$ anthropogenic emissions in NYC were increased by $16 \%$ from 2008 to 2011 , mainly in miscellaneous nonindustrial not elsewhere classified (NEC) and waste disposal emissions, and further increased by $37 \%$ from 2011 to 2014 primarily in fuel combustion. As aforementioned, emissions of $\mathrm{Hg}$ in the eastern US decreased by $13 \%$ from 2008 to 2011 and increased by $2 \%$ from 2011 to 2014 . In contrast, total $\mathrm{SO}_{2}$ emissions in NYC decreased steadily by $30 \%$ from 2008 to 2011 followed by a further decrease of $43 \%$ to 2014, while over the eastern US total $\mathrm{SO}_{2}$ emissions decreased by $48 \%$ from 2008 to 2011, furthered by another $29 \%$ decrease in 2014. Specifically, NYC launched the Clean Heat program in winter 2008-2009 resulting in a $69 \%$ decrease in $\mathrm{SO}_{2}$ concentrations averaged over the citywide street-level monitoring sites in winter 2012-2013 (NYC Health, 2013; https://www1.nyc.gov/assets/doh/downloads/ pdf/environmental/air-quality-report-2013.pdf). The Bronx data also reflected the effect of such emission reductions, with a $58 \%$ decrease in the seasonal median mixing ratio of $\mathrm{SO}_{2}$ from $9.2 \mathrm{ppbv}$ in winter 2009 to $2.8 \mathrm{ppbv}$ in winter 2015 (Fig. S6). As for $\mathrm{NO}_{2}$, fuel and mobile combustion emissions comprised $>99.5 \%$ of the total $\mathrm{NO}_{x}$ emissions in $\mathrm{NYC}$ and $\sim 90 \%$ over the eastern US. NYC $\mathrm{NO}_{x}$ emissions changed insignificantly (1\%) from 2008 to 2011 and by $15 \%$ from 2011 to 2014, while eastern US mobile and fuel combustion emissions were decreased by 16 and $33 \%$, respectively, from 2008 to 2011, and further decreased by 13 and $9 \%$, respectively, to 2014 . These varying changes possibly contributed to confounding the emission signature of GEM vs. $\mathrm{NO}_{x}$ and altered that of GEM vs. $\mathrm{SO}_{2}$.

The effect of local emissions can be accentuated by the correlation between GEM and $\mathrm{SO}_{2}$ and between GEM and $\mathrm{NO}_{2}$ for the $\mathrm{SO}_{2}$ and $\mathrm{NO}_{2}$ mixing ratios, exceeding their respective seasonal 95th percentile concentrations. However, nearly no correlation between GEM and $\mathrm{SO}_{2}$ or between
GEM and $\mathrm{NO}_{2}$ was found in this subset of data (Table 2). It should therefore be cautioned that tracer correlation could not be used to identify source types of GEM or estimate emission ratios of GEM to $\mathrm{SO}_{2}$ or $\mathrm{NO}_{2}$ in NYC.

\subsection{Regional vs. local contributions to NYC ambient GEM concentrations}

HYSPLIT dispersion simulations were used to obtain a quantitative comparison of the effects of sources outside and inside NYC on NYC ambient concentrations of GEM. As stated in Sect. 2.3, the modeling domain extended westward to $\mathrm{OH}$ and southward to northern VA and northward to include New England (Fig. 10a), with a total of 522 counties reporting $\mathrm{Hg}$ emissions. As described earlier, two scenarios were designed for model simulations:

1. a scenario with the emission sources in all 522 counties within the domain

2. a scenario with the mercury emission sources in all but the five boroughs in NYC.

Simulations of scenario no. 2 quantify the contribution of sources outside of NYC to Hg concentrations in NYC, and the difference in the concentrations in NYC between the two scenario s quantifies the contribution of NYC local sources to $\mathrm{Hg}$ concentrations in NYC.

Shown in Fig. 10b is the contribution, in percentage of the total contribution from all anthropogenic emissions in the domain, to NYC ambient concentrations of GEM from anthropogenic emissions alone from local sources, and in Fig. 10c is the contribution of emissions from regional anthropogenic sources. There was clearly interannual variability in the contribution of local versus regional anthropogenic sources. Local emissions averaged a contribution of $25 \%$ in all winters of 2009-2015, with the period minimum of $17 \%$ in winter 2011 and the maximum of $33 \%$ in winter 2013 (Fig. 10b). Conversely, the contribution of regional sources averaged a contribution of $75 \%$ in all winters, with the largest $83 \%$ in winter 2011 and the lowest $67 \%$ in winter 2013 (Fig. 10c). 
Compared to contributions in the winter of the same year, those from local sources were larger (by up to $12 \%$ in 2009) in the summers of 2009, 2011, 2012, and 2014, close in summer 2010, and 10\% smaller in summer 2013 (Fig. 10b).

A close examination revealed largely consistent relation between NYC GEM mixing ratios and source contributions. As suggested in Sect. 3.2, the Bronx experienced the lowest concentrations of GEM in all percentile values in winter 2010, and yet, interestingly, the simulated local contribution in winter 2010 was in the midrange of the seven winters. This indicates that the particularly low background concentration in the sweeping northerly flow led to less regional contribution to NYC Hg concentrations than regional sources would in other years. In contrast, winter 2014 saw the highest 25th, 50th, 75th, and 90th percentile concentrations of GEM, and yet the contribution of local sources $(\sim 22 \%)$ was not even higher than average (25\%). As aforementioned, in winter 2014 the eastern US was most likely under the least dynamic conditions conducive to regional buildup of air pollution, which resulted in a higher-than-average contribution from regional sources and conversely lower-thanaverage contribution from local sources (Fig. 10c). Consistent with GEM, the lower percentile mixing ratios of $\mathrm{CO}$, $\mathrm{SO}_{2}$, and $\mathrm{NO}_{2}$ appeared to be elevated or stopped decreasing compared to those in the previous year (Figs. S5, S6).

The HYSPLIT dispersion model simulations suggested that close to three-quarters of the anthropogenically induced concentration of GEM in NYC was from regional sources. It should be pointed out that other factors and/or processes, such as legacy and natural emissions, deposition, meteorology, and/or large-scale circulation, might have competed with the effect of anthropogenic emission reductions. Nearly $90 \%$ of the model simulation domain is covered by vegetation. SMOKE model output in Ye et al. (2017) suggested that the ratio of anthropogenic to legacy and natural emissions was 0.3 over the domain. Legacy and natural emissions could become dominant under warmer and wetter conditions in summer. Moreover, $\mathrm{Hg}$ deposition could be impacted by changes in physical parameters such as light, temperature, and plant species (Rutter et al., 2011). Indeed, changes of -30 to $50 \%$ in $\mathrm{Hg}$ deposition were simulated for the eastern US from the 2000s to the 2050s due to changes in precipitation (Megaritis et al., 2014). Net GEM surface emissions were estimated to be dominant in summer and net dry deposition was estimated to be dominant in other seasons at the majority of AMNet monitoring sites in eastern North America (Zhang et al., 2016). Since Hg deposition and legacy emissions are closely linked, these studies indicate potential changes in legacy emissions in response to variable meteorological conditions and changing climate with subsequent effects on atmospheric $\mathrm{Hg}$ concentrations. Therefore, with legacy and natural emissions accounted for, regional contributions to NYC ambient $\mathrm{Hg}$ concentrations would be even more dominant.
Caution needs to be taken in interpreting the model results due to the limitation of the modeling exercise. First, to save computational time, the simulation domain used in this study was smaller than is ideal, and thus with a larger regional domain, the significance of regional anthropogenic sources could be enhanced. Second, the HYSPLIT dispersion model accounts only for long-range transport of a pollutant from sources within the domain, without considering chemical transformation, gas-to-particle partitioning, atmospheresurface exchange of mercury, loss through deposition, and background concentrations. This being said, for a compound such as GEM with a lifetime of 6-12 months, dispersion model simulations would be adequate for providing relative contributions of regional and local sources to ambient concentrations at a location of interest in continental midlatitudes.

\section{Summary}

For the Bronx site in NYC, distinct annual cycles of GEM were found in 2009 and 2010, with higher concentrations in warm seasons than in cool seasons by $10-20$ ppqv $(\sim 10$ $25 \%)$, consistent with urban annual cycles reported in the literature. This annual cycle was not reproduced in 2011, as anomalously low concentrations occurred in that warm season, and resumed in 2014. Such temporal variability in the urban GEM concentration was found to be driven by that in large-scale circulation. Seasonal median mixing ratios of GEM were found to be correlated with both the North American TAI and TII in winter and with TII in summer. Further, the intensity and position of the Bermuda High pressure system had a significant impact on Bronx GEM concentrations in warm seasons. Winter 2014 through spring 2015 experienced an anomalously strong influence from the Bermuda High, resulting in the largest GEM mixing ratios of the entire study period in all percentile values throughout the year. The regional influence on GEM concentrations in the Bronx was corroborated by significant, year-round GEM-CO correlation ( $r$ up to $0.69, p \sim 0$ ) during 2008-2013. This correlation disappeared or became minimal from winter 2014 through spring 2015 , resulting possibly from their very different emission changes in the eastern US.

HYSPLIT dispersion model simulations suggested that regional sources outside of NYC contributed to $\sim 75 \%$ (67$83 \%$ ) of the anthropogenic portion of the ambient GEM concentration and NYC emissions contributed the remaining $\sim 25 \%(17-33 \%)$. Significant interannual variation in the regional and local contributions was found to be consistent with that in large-scale circulation. The fact that there was no clearly defined trend in GEM concentrations at the Bronx site during the study period, despite anthropogenic emission reductions in the eastern US from 2008 to 2014, suggested that other factors and/or processes, such as large-scale circulation 
and legacy and/or natural emissions, might have dominated over anthropogenic emission reductions.

The North Atlantic subtropical high during 1978-2007 had reportedly become more intense, and its western ridge had displaced westward with an enhanced meridional movement ( $\mathrm{Li}$ et al., 2011). The increasing intensity and spatial extent of the high-pressure system could cast a strong influence on the northeastern US with a subsequent effect on ambient concentrations of $\mathrm{Hg}$ via regional buildup and changing legacy emissions. This could dominate over the effect of anthropogenic emission reductions, as suggested by this study. Indeed, Zhu and Liang (2013) recommended that strong decadal variations in the Bermuda High should be considered in the US air quality dynamic management. Therefore, controlling urban ambient concentrations of $\mathrm{Hg}$ needs to account for the overall impact of multiple factors, which may not be dominated by emission reductions.

Data availability. The measurement data used in this study could be obtained from AMNet of NADP (http://nadp.sws.uiuc.edu/amn/ data.aspx).

\section{The Supplement related to this article is available online at https://doi.org/10.5194/acp-17-11655-2017- supplement.}

Competing interests. The authors declare that they have no conflict of interest.

Acknowledgements. This work was funded by the Environmental Protection Agency grant agreement no. 83521501. We are grateful to Mark L. Olson and Thomas R. Bergerhouse of NADP and University of Illinois at Urbana-Champaign and Kevin Civerolo of NYS DEC for making the Bronx GEM data available. We also thank Kevin Civerolo for helpful comments and input. The authors gratefully acknowledge the NOAA Air Resources Laboratory for free access to HYSPLIT. We greatly appreciate the two anonymous reviewers' thoughtful and constructive comments, which helped to improve the paper significantly. Although this paper was reviewed internally, it does not necessarily reflect the views or policies of the NYS DEC.

Edited by: Aurélien Dommergue

Reviewed by: three anonymous referees

\section{References}

Adler, F. R. and Tanner, C. J.: Urban Ecosystems: Ecological Principles for the Built Environment, 1st Edn., Cambridge University Press, 353 pp., 2013.

Bradbury, J. A., Keim, B. D., and Wake, C. P.: U.S. East Coast Trough Indices at $500 \mathrm{hPa}$ and New England Winter Climate Variability, J. Climate, 15, 3509-3517, 2002.

Brown, R. J. C., Goddard, S. L., Butterfield, D. M., Brown, A. S., Robins, C., Mustoe, C. L., and McGhee, E. A.: Ten years of mercury measurement at urban and industrial air quality monitoring stations in the UK, Atmos. Environ., 109, 1-8, 2015.

Chen, L., Liu, M., Xu, Z., Fan, R., Tao, J., Chen, D., Zhang, D., Xie, D., and Sun, J.: Variation trends and influencing factors of total gaseous mercury in the Pearl River Delta - A highly industrialized region in South China influenced by seasonal monsoons, Atmos. Environ., 77, 757-766, 2013.

Cheng, I., Lu, J., and Song, X.: Studies of potential sources that contributed to atmospheric mercury in Toronto, Canada, Atmos. Environ., 43, 6145-6158, 2009.

Choi, H., Huang, J., Mondal, S., and Holsen, T. M.: Variation in concentrations of three mercury $(\mathrm{Hg})$ forms at a rural and a suburban site in New York State, Sci. Total Environ., 448, 96-106, https://doi.org/10.1016/j.scitotend.2012.08.052, 2013.

Civerolo, K. L., Rattigan, O. V., Felton, D. H., Hirsch, M. J., and DeSantis, S.: Mercury wet deposition and speciated air concentrations from two urban sites in New York State; temporal patterns and regional context, Aeros. Air Qual. Res., 14, 1822-1837, https://doi.org/10.4209/aaqr.2014.03.0052, 2014.

Denis, M. S., Song, X., Lu, J. Y., and Feng, X.: Atmospheric gaseous elemental mercury in downtown Toronto, Atmos. Environ., 40, 4016-4024, https://doi.org/10.1016/j.atmosenv.2005.07.078, 2006.

Draxler, R. R.: HYSPLIT4 user's guide, NOAA Tech. Memo. ERL ARL-230, NOAA Air Resources Laboratory, Silver Spring, MD, 1999.

Draxler, R. R. and Hess, G. D.: Description of the HYSPLIT_4 modeling system, NOAA Tech. Memo, ERL ARL-224, NOAA Air Resources Laboratory, Silver Spring, MD, 24 pp., 1997.

Draxler, R. R. and Hess, G. D.: An overview of the HYSPLIT_4 modeling system of trajectories, dispersion, and deposition, Aust. Meteor. Mag., 47, 295-308, 1998.

Driscoll, C. T., Mason, R. P., Chan, H. M., Jacob, D. J., and Pirrone, N.: Mercury as a global pollutant: sources, pathways, and effect, Environ. Sci. Technol., 47, 4967-4983, 2013.

Engle, M. A., Tate, M. T., Krabbenhoft, D. P., Schauer, J. J., Kolker, A., Shanley, J. B., and Bothner, M. H.: Comparison of atmospheric mercury speciation and deposition at nine sites across central and eastern North America, J. Geophys. Res.-Atmos., 115, D18306, https://doi.org/10.1029/2010JD014064, 2010.

Fang, F., Wang, Q., and Li, J.: Urban environmental mercury in Changchun, a metropolitan city in Northeastern China: source, cycle, and fate, Sci. Total Environ., 330, 159-170, 2004.

Feng, X., Tang, S., Shang, L., Yan, H., Sommar, J., and Lindqvist, O.: Total gaseous mercury in the atmosphere of Guiyang, P. R. China, Sci. Total Environ., 304, 61-72, 2003.

Fu, X. W., Zhang, H., Yu, B., Wang, X., Lin, C.-J., and Feng, X. B.: Observations of atmospheric mercury in China: a critical review, Atmos. Chem. Phys., 15, 9455-9476, https://doi.org/10.5194/acp-15-9455-2015, 2015. 
Gabriel, M. C., Williamson, D. G., Brooks, S., and Lindberg, S.: Atmospheric speciation of mercury in two contrasting Southeastern US airsheds, Atmos. Environ., 39, 4947-4958, 2005.

Gay, D. A., Schmeltz, D., Prestbo, E., Olson, M., Sharac, T., and Tordon, R.: The Atmospheric Mercury Network: measurement and initial examination of an ongoing atmospheric mercury record across North America, Atmos. Chem. Phys., 13, 1133911349, https://doi.org/10.5194/acp-13-11339-2013, 2013.

Hall, C. B., Mao, H., Ye, Z., Talbot, R., Ding, A., Zhang, Y., Zhu, J., Wang, T., Lin, C. J., Fu, C., and Yang, X.: Sources and dynamic processes controlling background and peak concentrations of TGM in Nanjing, China, Atmosphere, 5, 124-155, 2014.

Jen, Y.-H., Yuan, C.-S., Hung, C.-H., Ie, I.-R., and Tsai, C.-M.: Tempospatial Variation and Partition of Atmospheric Mercury during Wet and Dry Seasons at Sensitivity Sites within a Heavily Polluted Industrial City, Aeros. Air Quality Res., 13, 13-23, 2013.

Kim, K. H. and Kim, M. Y.: The temporal distribution characteristics of total gaseous mercury at an urban monitoring site in Seoul during 1999-2000, Atmos. Environ., 35, 4253-4263, 2001.

Kim, K. H., Yoon, H. O., Brown, R. J., Jeon, E. C., Sohn, J. R., Jung, K., Park, C. G., and Kim, I. S.: Simultaneous monitoring of total gaseous mercury at four urban monitoring stations in Seoul, Korea, Atmos. Res., 132, 199-208, 2013.

Kim, K.-H., Brown, R. J., Kwon, E., Kim, I.-S., and Sohn, J.-R.: Atmospheric mercury at an urban station in Korea across three decades, Atmos. Environ., 131, 124-132, 2016.

Landis, M. S., Stevens, R. K., Schaedlich, F., and Prestbo, E. M.: Development and Characterization of an Annular Denuder Methodology for the Measurement of Divalent Inorganic Reactive Gaseous Mercury in Ambient Air, Environ. Sci. Technol., 36, 3000-3009, 2002.

Lan, X., Talbot, R., Castro, M., Perry, K., and Luke, W.: Seasonal and diurnal variations of atmospheric mercury across the US determined from AMNet monitoring data, Atmos. Chem. Phys., 12, 10569-10582, https://doi.org/10.5194/acp-12-105692012, 2012.

Lan, X., Talbot, R., Laine, P., Lefer, B., Flynn, J., and Torres, A.: Seasonal and diurnal variations of total gaseous mercury in urban Houston, TX, USA, Atmosphere, 5, 399-419, 2014.

Li, W., Li, L., Fu, R., Deng, Y., and Wang, H.: Changes to the North Atlantic Subtropical High and Its Role in the Intensification of Summer Rainfall Variability in the Southeastern United States, J. Climate, 24, 1499-1506, 2011.

Lindberg, S., Bullock, R., Ebinghaus, R., Engstrom, D., Feng, X., Fitzgerald, W., Pirrone, N., Prestbo, E., and Seigneur, C.: A synthesis of progress and uncertainties in attributing the sources of mercury in deposition, Ambio, 36, 19-32, 2007.

Lindberg, S. E. and Stratton, W. J.: Atmospheric mercury speciation: concentrations and behavior of reactive gaseous mercury in ambient air, Environ. Sci. Technol., 32, 49-57, 1998.

Liu, B., Keeler, G. J., Dvonch, J. T., Barres, J. A., Lynam, M. M., Marsik, F. J., and Morgan, J. T.: Temporal variability of mercury speciation in urban air, Atmos. Environ., 41, 1911-1923, https://doi.org/10.1016/j.atmosenv.2006.10.063, 2007.

Liu, B., Keeler, G. J., Dvonch, J. T., Barres, J. A., Lynam, M. M., Marsik, F. J., and Morgan, J. T.: Urban-rural differences in atmospheric mercury speciation, Atmos. Environ., 44, 2013-2023, 2010 .
Lombard, M. A. S., Bryce, J. G., Mao, H., and Talbot, R.: Mercury deposition in Southern New Hampshire, 2006-2009, Atmos. Chem. Phys., 11, 7657-7668, https://doi.org/10.5194/acp11-7657-2011, 2011.

Lyman, S. N. and Gustin, M. S.: Determinants of atmospheric mercury concentrations in Reno, Nevada, USA, Sci. Total Environ., 408, 431-438, 2009.

Mao, H. and Talbot, R.: Speciated mercury at marine, coastal, and inland sites in New England - Part 1: Temporal variability, Atmos. Chem. Phys., 12, 5099-5112, https://doi.org/10.5194/acp12-5099-2012, 2012.

Mao, H., Talbot, R. W., Sigler, J. M., Sive, B. C., and Hegarty, J. D.: Seasonal and diurnal variations of $\mathrm{Hg}^{\circ}$ over New England, Atmos. Chem. Phys., 8, 1403-1421, https://doi.org/10.5194/acp8-1403-2008, 2008.

Mao, H., Cheng, I., and Zhang, L.: Current understanding of the driving mechanisms for spatiotemporal variations of atmospheric speciated mercury: a review, Atmos. Chem. Phys., 16, 1289712924, https://doi.org/10.5194/acp-16-12897-2016, 2016.

Megaritis, A. G., Murphy, B. N., Racherla, P. N., Adams, P. J., and Pandis, S. N.: Impact of climate change on mercury concentrations and deposition in the eastern United States, Sci. Total Environ., 487, 299-312, https://doi.org/10.1016/j.scitotenv.2014.03.084, 2014.

Nair, U. S., Wu, Y., Walters, J., Jansen, J., and Edgerton, E. S.: Diurnal and seasonal variation of mercury species at coastalsuburban, urban, and rural sites in the southeastern United States, Atmos. Environ., 47, 499-508, 2012.

Peterson, C., Gustin, M., and Lyman, S.: Atmospheric mercury concentrations and speciation measures from 2004 to 2007 in Reno, Nevada, USA, Atmos. Environ., 43, 4646-4654, https://doi.org/10.1016/j.atmosenv.2009.04.053, 2009.

Rutter, A. P., Schauer, J. J., Shafer, M. M., Creswell, J., Olson, M. R., Clary, A., Robinson, M., Parman, A. M., and Katzman, T. L.: Climate Sensitivity of Gaseous Elemental Mercury Dry Deposition to Plants: Impacts of Temperature, Light Intensity, and Plant Species, Environ. Sci. Technol., 45, 569-575, 2011.

Selin, N. E.: Global change and mercury cycling: Challenges for implementing a global mercury treaty, Environ. Toxicol. Chem., 33, 1202-1210, 2014.

Seo, Y.-S., Jeong, S.-P., Holsen, T. M., Han, Y.-J., Choi, E., Park, E. H., Kim, T. Y., Eum, H.-S., Park, D. G., Kim, E., Kim, S., Kim, J.-H., Choi, J., and Yi, S.-M.: Characteristics of total gaseous mercury (TGM) concentrations in an industrial complex in South Korea: impacts from local sources, Atmos. Chem. Phys., 16, 10215-10228, https://doi.org/10.5194/acp-16-102152016, 2016.

Sprovieri, F., Pirrone, N., Ebinghaus, R., Kock, H., and Dommergue, A.: A review of worldwide atmospheric mercury measurements, Atmos. Chem. Phys., 10, 8245-8265, https://doi.org/10.5194/acp-10-8245-2010, 2010.

Stamenkovic, J., Lyman, S., and Gustin, M. S.: Seasonal and diel variation of atmospheric mercury concentrations in the Reno (Nevada, USA) airshed, Atmos. Environ., 41, 6662-6672, 2007.

Stein, A. F., Draxler, R. R., Rolph, G. D., Stunder, B. J. B., Cohen, M. D., and Ngan, F.: NOAA's HYSPLIT atmospheric transport and dispersion modeling system, B. Am. Meteorol. Soc., 96, 2059-2077, https://doi.org/10.1175/BAMS-D-14$00110.1,2015$. 
Wang, Y., Huang, J., Hopke, P. K., Holsen, T. M., Rattigan, O. V., Chalupa, D. C., and Utell, M. J.: Effect of the shutdown of a large coal-fired power plant on ambient mercury species, Chemosphere, 92, 360-367, 2013.

$\mathrm{Xu}, \mathrm{X}$. , Akhtar, U., Clark, K., and Wang, X.: Temporal Variability of Atmospheric Total Gaseous Mercury in Windsor, ON, Canada, Atmosphere, 5, 536-556, https://doi.org/10.3390/atmos5030536, 2014.

Ye, Z., Mao, H., Hogrefe, C., Zhang, Y., and Jaegle, L.: Regional photochemical model evaluation of speciated ambient mercury and mercury wet and dry deposition, J. Adv. Model. Earth Sys., in review, 2017.

Zhang, L., Wang, S. X., Wang, L., and Hao, J. M.: Atmospheric mercury concentration and chemical speciation at a rural site in Beijing, China: implications of mercury emission sources, Atmos. Chem. Phys., 13, 10505-10516, https://doi.org/10.5194/acp-13-10505-2013, 2013.
Zhang, L., Wu, Z., Cheng, I., Wright, L. P., Olson, M. L., Gay, D. A., Risch, M. R., Brooks, S., Castro, M. S., Conley, G. D., Edgerton, E. S., Holsen, T. M., Luke, W., Tordon, R., and Weiss-Penzias, P.: The estimated six-year mercury dry deposition acrossNorth America, Environ. Sci. Technol., 50, 12864-12873, https://doi.org/10.1021/acs.est.6b04276, 2016.

Zhou, Y., Mao, H., Demerjian, K., Hogrefe, C., and Liu, J.: Regional and Hemispheric Influences on Temporal Variability in Baseline Carbon Monoxide and Ozone over the Northeast US, Atmos. Environ., 164, 309-324, 2017.

Zhu, J., Wang, T., Talbot, R., Mao, H., Hall, C. B., Yang, X., Fu, C., Zhuang, B., Li, S., Han, Y., and Huang, X.: Characteristics of atmospheric Total Gaseous Mercury (TGM) observed in urban Nanjing, China, Atmos. Chem. Phys., 12, 12103-12118, https://doi.org/10.5194/acp-12-12103-2012, 2012.

Zhu, J. and Liang, X.-Z.: Impacts of the Bermuda High on Regional Climate and Ozone over the United States, J. Climate, 26, 10181026, 2013. 